\title{
PENGELOLAAN PROGRAM PEMBELAJARAN PENDIDIKAN ALTERNATIF KOMUNITAS BELAJAR QARYAH THAYYIBAH DI SALATIGA JAWA TENGAH
}

\author{
MANAGEMENT LEARNING PROGRAM ALTERNATIVE EDUCATION \\ COMMUNITY LEARNING QARYAH THAYYIBAH IN SALATIGA CENTRAL JAVA
}

\author{
Imam Shofwan, Sodiq Aziz Kuntoro \\ IKIP Veteran Semarang, Universitas Negeri Yogyakarta \\ shofwan.imam@gmail.com, sodiq_azis@uny.ac.id
}

\begin{abstract}
Abstrak
Penelitian ini bertujuan mengungkapkan persepsi tentang pelaksanaan program pendidikan alternatif melalui pembelajaran di Komunitas Belajar Qaryah Thayyibah (KBQT) berkaitan dengan: (1) Filsafat pendidikan, (2) Pengelolaan pembelajaran, (3) Hasil pembelajaran, (4). Faktor pendukung dan penghambat.Penelitian ini menggunakan pendekatan kualitatif fenomenologi interpretitif. Subyek penelitian adalah pendiri, pendamping dan warga belajar. Pengumpulan data dilakukan dengan: (1) riset kepustakaan, (2) teknik dokumentasi, (3) riset lapangan. Metode analisis data dilakukan dengan cara: (a) reduksi data, (b) penyajian data, (c) penarikan kesimpulan. Hasil penelitian ini mengungkapkan bahwa: (1) Filosofi pendidikan menggunakan konsep Paulo Friere dengan pembelajaran kontruktivisme maupum rekontruktivisme, (2) Pengelolaan program pembelajaran berkaitan: (a) perencanaan yang dilakukan oleh, untuk dan bagi komunitas; (b) pelaksanaan pembelajaran dilakukan secara fleksibel; (c) evaluasi dilakukan dengan melaporkan catatan kegiatan belajar, (3) Hasil pembelajaran diwujudkan dalam bentuk karya, (4) Faktor pendukungnya adalah teman komunitas, dan faktor penghambatnya adalah kurang memahami konsep pembelajaran serta kurangnya pendampingan yang efektif.
\end{abstract}

Kata Kunci: pendidikan alternatif, komunitas belajar

\begin{abstract}
This study aims to reveal the perception of an alternative education program through the implementation of learning in Community Learning Qaryah Thayyibah (QTLC) relating to: (1) Philosophy of education, (2) learning management, (3) learning outcome, (4). Enabling and inhibiting factors. This study used a qualitative approach interpretitif phenomenology. Subjects were founders, mentors and learners. Data collected by: (1) the research literature, (2) technical documentation, (3) research field. Methods of data analysis done by: (a) data reduction, (b) the presentation of the data, (c) drawing conclusions. The research results revealed that: (1) educational philosophy using the concept of Paulo Friere with constructivism learning, (2) Management related learning program: (a) planning done by, to and for the community, (b) the implementation of flexible learning is done; (c) evaluation is done by reporting record learning activities, (3) learning outcomes manifested in the form of work, (4) is a factor supporting community friends, and inhibiting factor is the lack of understanding of the concept of learning as well as the lack of effective mentoring
\end{abstract}

Keywords: alternative education, community learning 


\section{PENDAHULUAN}

Pendidikan merupakan unsur yang paling strategis bagi pembangunan suatu bangsa. Peran adanya pendidikan akan berpengaruh kepada sumberdaya manusia secara kualitas dan kuantitas, sehingga dapat meningkatkan kesejahteraan dan kemakmuran masyarakat dalam suatu negara dan pada akhirnya dapat mengangkat derajat dan martabat bangsa itu sendiri. Suatu bangsa atau negara dapat dikatakan semakin maju dan berkembang diantaranya, apabila dalam pembangunan di bidang pendidikan diberikan perhatian secara maksimal dengan upaya penyediaan fasilitas, sarana dan prasarana untuk memenuhi pendidikan masyarakatnya.

Melalui peran pendidikan merupakan upaya yang paling efektif dalam mengatasi kendala keterbatasan kemampuan masyarakat siap berpartisipasi dalam proses pembangunan, (Ali, 2009, p.32). Dalam hal ini yang perlu dilakukan oleh pemerintahan adalah melakukan terobosan atau inovasi baru dalam menerapkan kebijakan pendidikan untuk menciptakan pendidikan yang berkualitas, sehingga berdampak kepada sumberdaya manusia yang bermutu.

Parameter atau ukuran manusia dapat dikatakan bermutu atau juga bisa disebut berkualitas adalah manakala individu atau seseorang sanggup menyelesaikan persoalan-persoalan dalam kehidupannya secara mandiri, akuntabilitas, kredibilitas dan beretika dalam sosial. Selain itu terus bersemangat mengembangkan pengetahuannya untuk dapat hidup lebih baik dan dapat berguna bagi orang lain atau dalam masyarakatnya.

Menurut Isjoni, (2012, p.viii) "kemandirian sendiri berproses sangat lama dan banyak memakan waktu, maka pengajaran untuk dapat mandiri harus sudah dimulai, dan diarahkan dalam pendidikan ke arah karya nyata". Selain mampu untuk menjadi manusia yang mandiri, yaitu pribadi yang mampu mengenal dan menerima dirinya sendiri dan lingkungannya, mampu mengarahkan dirinya dan selanjutnya dapat mengembangkan potensi dirinya untuk mewujudkan dirinya secara optimal secara terus menerus sesuai dengan tuntutan dan kebutuhan dalam kehidupannya.

Pendidikan sesungguhnya dapat dikatakan sebagai salah satu bentuk strategi budaya tertua bagi manusia untuk memertahankan keberlangsungan eksistensi dalam kehidupan. Arti budaya, menurut Shaleh, (2011, p.36) yaitu "aneka ragam tingkah laku, pola pikiran, pergaulan, dan keserasian dalam hidup yang diterima/diperbuat oleh anggota masyarakat, sehingga mereka berbeda dari masyarakat yang lainnya".

Adapun tujuan pendidikan menurut Delors, yang kemudian dikenal dengan empat pilar pendidikan versi UNESCO (1996) yang harus mendapatkan perhatian, yaitu: (1) learning to know, untuk mengetahui; (2) learning to do, belajar untuk dapat berbuat; (3) learning to be, belajar untuk menjadi dirinya; dan (4) learning to live together, belajar untuk hidup bersama dengan orang lain.

Sementara itu, tujuan pendidikan menurut UNDP dalam Human Development Report 1999 yang dikenal dengan istilah The Seven Freedoms (Dalam Rifai, 2011, pp.51-52) adalah sebagai berikut: (1) Freedon from discrimination; bebas dari perlakuan diskriminatif, (2) Freedom from fear; bebas dari rasa ketakutan, (3) Freedom of thought, speech, and participate; bebas untuk berfikir, berbicara dan berpartisipasi, (4) Freedom from want; bebas dari berbagai keinginan, (5) Freedom to develop and realize; bebas untuk mengembangkan dan merealisasi, (6) Freedom from injustice and violations; bebas dari tindak ketidak adilan dan kekerasan, (7) Freedom from undecent work; bebas dari pekerjaan yang tidak patut.

Menurut Prasojo (2012, p.19) mengenai masalah pendidikan adalah "suatu gejala universal yang melanda setiap negara, baik negara maju maupun berkembang yang perbedaannya terletak pada corak strategi dalam solusi pemecahan yang terbaik, dan sampai sekarang masih menjadi dilema”.

Berkaitan dengan pendidikan formal fakta di lapangan, sekarang ini tidak sedikit yang lebih mengarah kepada pasar kapitalis dengan kata lain pendidikan formal dapat dikatakan perusahaan di bidang jasa dan para keluarga dengan anaknya dikatakan seba- 
gai calon konsumen yang mempunyai pola hubungan antara sekolah dan peserta didik.

Ada beberapa alasan yang mendasari terbentuknya komersialisasi pendidikan di Indonesia, diantara menurut Suharto, (2010, pp.216-217) adalah sebagai berikut: (1) Swastanisasi yang semakin mengglobal, (2) Pemerintah merasa tidak mempunyai dana yang cukup untuk membiayai sektor pendidikan, (3) Pemerintah tidak mampu mengelola pendidikan sebagai sektor publik dengan baik, (4) Lembaga pendidikan kurang memiliki kreatifitas dan inovasi dalam melakukan "fund raising".

Komersialisme pendidikan inilah yang mengakibatkan kepada dampak sosial yang tidak diinginkan oleh masyarakat terutama oleh masyarakat ekonomi bawah dikarenakan menjadi mahalnya pendidikan di Indonesia, Gap dalam kualitas pendidikan, diskriminasi, stigmatisasi, perubahan misi pendidikan, konsumerisme gaya hidup dan memperburuk kualitas SDM serta rantai kemiskinan yang mustahil diputuskan oleh pendidikan karena tujuan pendidikan sudah keluar dari jalur dalam mencerdaskan kehidupan masyarakat baik orang kaya dan miskin.

Selain itu sistem pendidikan sekarang ini menurut Freire, (200o, p.50) "pendidikan ibarat sebagai sebuah konsep "bank" (banking concept of education) di mana pelajar diberi ilmu pengetahuan agar kelak ia dapat mendatangkan hasil lipat ganda".

Selain itu pada kenyataannya pembelajaran di sekolah masih bersifat konvensional yaitu pendidikan sistem belanda yang menyamaratakan kemampuan dan kecerdasan anak diangap sama rata semua bagaikan kertas putih yang siap untuk ditulisi. Padahal dalam diri anak sejak lahir sudah membawa berbagai kecerdasan yang disebut dengan multiple intelegency.

Adanya permasalahan tersebut bisa menjadi ketimpangan mutu dalam pendidikan, hal ini menurut Dwiningrum (2001, p.10) ada tiga sebab pokok ketimbangan yang berkembang, yakni:

Pertama, pendidikan mengalami pereduksian makna, yaitu proses menghafal dan keterampilan mengerjakan soal ujian.
Kedua, pendidikan terjerumus ke dalam proses komersialisasi, di mana pendidikan menjadi komiditi yang diperjual belikan dan dikelolala seperti dunia industri yang cenderung berorientasi kepada mencari keuntungan/profit oriented. Ketiga, pendidikan hanya melahirkan proses superior sekolah, yakni sekolah menjadi semakin digdaya, berjarak, dan menekan orangtua siswa, baik secara halus dan terang-terangan.

Kelemahan sistem pendidikan menurut buku Kompas, (2007, pp.150-151) dapat dikategorikan menjadi beberapa kelompok yang besar, antara lain ialah lingkungan kita belum mendidik, pendidikan yang belum memperhatikan ciri anak, siswa dibebani biaya pendidikan, belum ada integrasi sistem pendidikan antara informal, nonformal dan formal, pendidikan yang cenderung menimbulkan diskriminatif, pembelajaran yang masih konvensional, pengajaran yang belum memiliki muatan pendidikan, pola pendidikan yang belum mengarah kepada strategi membangun bangsa, pendidikan yang belum menyenangkan siswa, belum memerdekakan bahkan terasa membelanggu, belum terjadi proses pembelajaran yang bermakna, pendidikan yang didominasi oleh kegiatan mengajar, pendidikan yang cenderung berorientasi kepada telektualitas, belum melakukan evaluasi hasil pendidikan, Pendidikan yang dijangka jauh harus mengintegrasikan antara ilmu dan agama yang keduanya untuk selamatkan manusia umumnya.

Adanya berbagai kelemahan tersebut, maka perlu melakukan pemikiran-pemikiran untuk mengembangkan pendidikan kita ke arah yang lebih baik. Sebagai alternatif pendidikan atas kritik kepada kebijakan pemerintah dari dahulu, maka munculnya berbagai ide seperti "teori Pendidikan Pembebasan" oleh Fraire, "teori Constructivist" oleh Brooks, teori Cultural Perspective" oleh Rhoads dan Black, "teori Collaborative Learning" oleh Bruffee. (Zamroni, 2000, p.155).

Melalui pendidikan alternatif dirasa dapat menjawab berbagai masalah kelemahan tentang pendidikan yang terjadi di Indonesia untuk seluruh masyarakat Indonesia, baik masyarakat kaya maupun masya- 
rakat miskin yang semuanya memerlukan kedudukan yang sama dalam bidang pendidikan. Untuk itu diperlukan sebuah pendidikan yang demokratis yaitu "pendidikan yang memberikan kesempatan yang sama kepada setiap anak untuk mendapatkan pendidikan di sekolah sesuai dengan kemampuannya" (Hasbullah, 1999, p.241).

Berbicara mengenai pendidikan alternatif, di Jawa Tengah adalah pendidikan alternatif berbasis komunitas bernama "Komunitas Belajar Qaryah Thayyibah" disingkat dengan KBQT yang layak untuk diteliti. Pemilihan pendidikan alternatif yang tepatnya berada di Kota Salatiga dijadikan sebagai subjek penelitian ini didasarkan kepada beberapa pertimbangan berikut: (1) KBQT berdiri sejak tahun 2007 di Desa Kalibening Kecamatan Tingkir Kota Salatiga yang merupakan pendidikan alternatif berbasis pada komunitas; (2) pengembangan pendidikan alternatif di KBQT dari tahun ke tahun, mengalami perkembangan yang disesuaikan dengan kebutuhan dari komunitas, oleh komunitas, dan untuk komunitas; (3) pengelolaan program pendidikan yang berbeda dengan sekolah formal dan keluarannya tidak kalah dengan pendidikan formal yang ada di lingkungan sekolah sekitar; (4) Suatu pendidikan yang baik berawal dari desa dengan memanfaatkan potensi sumberdaya alam desa dan membelajarkan sumberdaya manusianya.

Inilah sebagai daya tarik alasan dalam melakukan penelitian yang pendidikan alternatif yang dapat bermanfaat untuk memberdayakan masyarakat dan mengembangkan sebuah desa yang mandiri, berkarya dengan memanfaatkan potensi lokal yang ada dan memberdayakan sumberdaya manusia.

Pendidikan alternatif inilah sebagai gagasan sekolah alternatif sebagai wujud keprihatinan masyarakat dalam menjawab pendidikan yang memihak masyarakat perekonomian lemah yang didirikan oleh Ahmad Bahrudin dari Salatiga Jawa Tengah dengan konsepnya "keberdayaan desa" yang diberi nama Qaryah Thayyibah yang artinya adalah "desa yang indah".

Supaya dapat mengetahui lebih mendetail, maka diperlukan penelitian lebih mendalam tentang pelaksanaan pendidikan alternatif yang dapat dikategorikan sebagai pendidikan nonformal sesuai dengan UU SISDIKNAS Bab I Pasal 1 (12) "Pendidikan nonformal adalah jalur pendidikan di luar pendidikan formal yang dapat dilaksanakan secara terstruktur dan berjenjang" yang pelaksanaan pendidikannya di luar sekolah atau disebut "pendidikan luar sekolah" dengan pelaksanaan atau penyelenggaraan pendidikan diatur yang dalam UndangUndang No. 20 Tahun 2003 Pasal 55 tentang "Pendidikan berbasis masyarakat" yang difokuskan pada "Pendidikan Alternatif Komunitas Belajar Qaryah Thayyibah di Kota Salatiga Propinsi Jawa Tengah.

\section{METODE}

Penelitian ini merupakan kualitatif untuk mengetahui persepsi mengenai pendidikan alternatif yang dilaksanakan di Komunitas Belajar Qaryah Thayyibah Salatiga Jawa Tengah. Penelitian ini dilaksanakan pada bulan Juni 2012 sampai dengan Juli 2013.

Penelitian ini menggunakan pendekatan kualitatif fenomenologi interpretitif. Subjek penelitian adalah pendiri, pendamping dan warga belajar KBQT. Pengumpulan data dilakukan dengan: (1) riset kepustakaan, (2) teknik dokumentasi, (3) riset lapangan dengan cara (a) observasi partisipasi, (b) wawancara, dan (c) fenomenologi. Teknik sampling dilakukan dengan purposive dan snowball sampling. Keabsahan hasil penelitian dilakukan dengan validitasi dan reabilitas. Metode analisis data dilakukan dengan cara: (a) reduksi data, (b) penyajian data, dan (c) verifikasi atau penarikan kesimpulan.

\section{HASIL PENELITIAN DAN PEMBAHASAN}

\section{Hasil Penelitian}

Hasil penelitian ini mengungkapkan bahwa: (1) Filosofi pendidikan KBQT adalah menggunakan filsafat pendidikan konsep Paulo Friere dan filsafat pembelajarannya menggunakan kontruktivisme mengenai konsep belajarnya dihadapkan pada permasalahan yang berhubungan langsung dengan kehidupan masyarakat, (2) Pengelolaan 
pembelajaran KBQT berkaitan dengan (a) perencanaan pembelajaran; (b) pelaksanaan pembelajaran; (c) evaluasi pembelajaran, 3) Hasil pembelajaran warga belajar KBQT berkaitan dengan output/keluaran adalah bisa berkarya sehingga mandiri dalam kehidupannya dan mudah menyesuaikan lingkungannya, serta outcome/dampak yaitu memunyai keterampilan yang lebih sehingga dapat diterima dan juga berguna bagi masyarakat, (4) Faktor pendukung dalam KBQT adalah temannya sendiri yang selalu mengingatkan dan memberikan dorongan, dan faktor penghambat KBQT ada secara internal adalah ketika warga belajar tidak memahami konsep pembelajaran, maka mereka tidak bisa maksimal dalam belajarnya, dan faktor eksternal adalah kurangnya pendampingan dalam memberikan dorongan kepada warga belajar.

\section{Pembahasan}

Suasana yang jauh dari keramaian, namun tidak jauh dari perkotaan. Itulah lokasi yang Komunitas Belajar Qaryah Thayyibah disingkat dengan KBQT yang beralamat di Jl. Raden Mas Said No. 19 RT o1 RW 02 Desa Kalibening, Kelurahan Kalibening, Kecamatan Tingkir, Kota Salatiga, Propinsi Jawa Tengah.

Lokasi yang berada kurang lebih berjarak $3 \mathrm{Km}$ dari pusat kota apabila perjalanan dari bundaran Tamansari atau Ramayana Mall. KBQT yang notabene merupakan sekolah, setingkat SMP (SMP Alternatif) dan SMA (SMA Alternatif) serta Universitas (Universitas Kehidupan) yang tidak mempunyai pagar sekolahan dan juga tidak ada aturan selayaknya sekolah pada umumnya.

Lokasi dari jalan besar masuk gang sekitar 100 meter kanan jalan dan nanti akan ketemu papan nama "LSD Qaryah Thayyibah" di situlah lokasinya pembelajara KBQT berada. Lokasi yang membingungkan peneliti pada awal mencari tempatnya dan mungkin orang yang akan bertamu jika tidak pernah kesana juga akan mungkin bernasib tidak jauh berbeda menjadi bingung, karena memang tidak mencerminkan seperti sekolahan pada umumnya.
Membingungkan, dikarenakan tidak ada tulisan sekolah alternatif atau yang berhubungan dengan nama sekolah seperti pada umumnya. Gedung yang belum selesai dibangun, akan tetapi sudah digunakan untuk pembelajaran, kebanyakan komunitas menyebutkan adalah "RC" resourch center yang bisa diartikan sebagai pusat sumber daya atau bahasa jawanya "Lumbung Deso" yang rencana akan dibangun empat tingkat yang lokasinya berdekatan dengan rumah pendiri dan juga mushola dan rumah masyarakat.

Inilah salah satu keunikan, dan yang membedakannya adalah rancangan gedung yang biasanya pada sekolah pada umumnya memiliki gedung yang di dalamnya ada banyak ruang. Ada ruangan laboratorium, ruang guru, ruang UKS (unit kesehatan sekolah), ruang TU (tata usaha) dan sebagainya. Akan tetapi di sini tidak ditemukan karena memang tidak dirancang seperti itu.

Filosofi Pendidikan dan Pembelajaran

Filosofi pendidikan yang anutnya adalah Paulo Friere dengan sistem (1) penyadaran; yang pada intinya adalah dalam proses pembelajaran ditumbuhkan kesadaran dirinya terhadap lingkungannya sehingga terciptanya berfikir kritis, dan (2) pembebasan; yang artinya tidak adanya pihak yang merasa berkuasa. Dengan adanya pemikiran seperti ini, maka warga belajar dalam melakukan pembelajarannya dilaksanakan dengan penuh dengan kesadaran tanpa ada unsur paksaan dari lingkungan eksternal.

Filosofi inilah yang menghapuskan adanya status perbedaan antara pendidik dan peserta didik. Yang menjadikan semua setara dalam pembelajaran, baik itu warga belajar atau pendamping yang pada intinya adalah sama-sama belajar. Selain itu dalam pendidikan yang dilakukannya adalah untuk menyadarkan warga belajarnya agar bisa mengelola sumberdaya alam atau potensi pedesaan untuk mewujudkan desa yang berdaya sesuai dengan namanya Qaryah Thayyibah yang artinya desa yang berdaya, desa yang baik.

Adapun mengenai tujuan pembelajarannya yang diterapkan adalah LCB 
(living center based) bahwa pendidikan yang baik adalah pendidikan untuk mengembangkan situasi belajar-mengajar yang memberikan kemampuan untuk peserta didik untuk berfikir kritis sehingga mereka dapat mengenali, menganalisa dan memecahkan masalah atau solusi-solusi yang timbul dalam dunia kehidupannya.

Selain itu, Komunitas Belajar Qaryah Tayyibah atau yang disingkat dengan sebutan KBQT aliran filosofinya adalah menganut filsafat kontruktivisme yaitu, dimana peserta didik dengan aktif memeroleh pengetahuannya sendiri sebagai subjek pembelajar, sehingga guru tidak berpartisipasi penuh dalam proses pembelajarannya. Selain itu juga melakukan rekontruktivisme, apabila dalam pembelajaran itu dirasa tidak sesuai dengan apa yang dilakukan dalam pembelajaran. Bukan menggunakan filsafat pendidikan yang menganut behavior yang di praktekkan pada sekolahan formal yaitu peserta didik menjadi objek pembelajar yang harus diberikan pengetahuan oleh gurunya, sehingga guru berpartisipasi penuh dalam proses pembelajarannya.

Selanjutnya berkaitan dengan teori belajarnya adalah menggunakan teori andragogi yaitu teori belajar orang dewasa yang salah satu faktanya adalah belajar sesuai dengan kebutuhan. Maka dengan adanya kebutuhan, maka warga belajar akan belajar. Dengan begitu proses belajarnya akan menjadikan semangat, karena belajarnya sesuai dengan apa yang diinginkan dan bukan karena keterpaksaan atau adanya perintah dari atasan kepada bawahan yang seperti dilakukan pada pendidikan formal. Yang dirasa pendidikan sekarang ini masih mempraktekkan pembelajaran model pekerja/buruh. Bagaimana tidak, apabila ada guru, maka siswa akan belajar, jika tidak ada guru maka siswa akan dengan asik bermain. Begitu juga apabila guru menyuruh untuk belajar, maka siswa akan mengikutinya.

Inilah sebenarnya pendidikan di Indonesia yang bisa dikatakan tidak humaniora atau memanusiakan manusia dan dalam belajarnya mereka disamaratakan semua bagaikan motor atau barang elektronik yang cara memperlakukannya dengan perlakuan yang sama. Selain itu juga dalam pembelajaran di sekolah tidak mengembangkan dialog kritis antara pendidik dan peserta didik, dan tidak saling belajar. Kegiatan pembelajaran di sekolah cenderung lebih didominasi oleh guru yang berada dalam posisi menekan, sedangkan peserta didik berada pada situasi yang ditekan.

Adapun berkaitan dengan penyelenggaraannya dilakukan oleh pendidikan nonformal atau pendidikan luar sekolah yang menurut Rogers (2005, p.73) mengatakan sebagai pendidikan Non-formal adalah didefinisikan sebagai pendidikan semua di luar dari sistem formal, dan mereka yang yang dianjurkan pendidikan nonformal sebagai solusi untuk mangatasi masalahmasalah pendidikan di masyarakat berkembang melihatnya sebagai diskrit entitas, dibedakan, dan dikelola.

Selain itu tujuan KBQT konsepnya adalah untuk memberdayakan potensi sumber daya manusia dan memanfaatkan potensi alam untuk menjadikan desa baik (thayyibah).

\section{Pengelolaan Program Pendidikan Melalui Pembelajaran}

Pengelolaan pembelajaran di KBQT dilakukan oleh komunitas sendiri yang dilakukan per kelas yang membahas mengenai permasalahan yang dihadapinya misalnya persoalan target yang akan dicapai. Selain itu adalah pengelolaan pembelajaran dilakukan per forum yaitu membahas mengenai kesenangan atau bakat/minat yang ingin dipelajari di komunitas dan saling bertukar pikiran dan informasi pengetahuan untuk saling membantu dalam menghasilkan karya setiap individunya.

Pendekatan pembelajaran semacam KBQT, sama seperti halnya dengan pendekatan pembangunan masyarakat, menurut Kamil, (2009, p.47) yaitu, model pembangunan murni datang dari masyarakat atau masyarakatlah yang memiliki keinginan (kebutuhan) kemudian merencanakan, mengelola proses pembangunan dan memeliharanya.

Adapun penyelenggaraannya dilakukan oleh pendidikan nonformal atau pendidikan luar sekolah yang menurut Rogers (2005, p.73) mengatakan "Non-formal edu- 
cation then was defined as all education outside of the formal system, And those who advocated NFE as a solution to the ills of education in developing sociaties saw it as adicrete entity, distinguishable, and manageable". Intinya adalah pendidikan Nonformal adalah didefinisikan sebagai pendidikan semua di luar dari sistem formal, dan mereka yang yang dianjurkan pendidikan nonformal sebagai solusi untuk mangatasi masalah-masalah pendidikan di masyarakat berkembang melihatnya sebagai diskrit entitas, dibedakan, dan dikelola.

Selain itu tujuan KBQT konsepnya adalah untuk memberdayakan potensi sumber daya manusia dan memanfaatkan potensi alam untuk menjadikan desa baik (thayyibah). Hal ini sesuai dengan pemikiran Placebo (2009, p.2) dengan pendapatnya "Education should therefore provide comprehensive knowledge, encompassing and cutting across the social and natural sciences and the humanities, thus providing insights on the interaction between natural and human resources, between development and environment". Intinya adalah pendidikan harus untuk itu memberikan pengetahuan komprehensif, meniadakan jarak antara sosial dan ilmu pengetahuan alam dan humaniora, wawasan dengan demikian menyediakan interaksi antara sumber daya alam dan sumber daya manusia, antara pembangunan dan lingkungan hidup.

Pengelolaan pembelajaran di KBQT dilakukan oleh komunitas sendiri yang dilakukan per kelas yang membahas mengenai permasalahan yang dihadapinya misalnya persoalan target yang akan dicapai. Selain itu adalah pengelolaan pembelajaran dilakukan per forum yaitu membahas mengenai kesenangan atau bakat/minat yang ingin dipelajari di komunitas dan saling bertukar pikiran dan informasi pengetahuan untuk saling membantu dalam menghasilkan karya setiap individunya.

Kesimpulannya pada intinya semua kegiatan dirancang, diorganisasikan, dan digerakkan, serta dibina komunitas itu sendiri. Dan apabila merasa mempunyai kesulitan baru meminta bantuan kepada pendamping untuk memberikan masukan dan solusi jalan keluarnya.
Kegiatan pengelolaan dalam pembelajaran yang terakhir adalah penilaian dan pengembangan pembelajaran. Seperti biasa setiap enam bulan sekali dilakukan GK (gelar karya) yang fungsinya untuk memberikan kritik dan masukan terhadap hasil karya yang telah dihasilkan mereka selama setengah tahun, dirangkum dalam berbagai sajian karya sebagai bahan evaluasi individu masing-masing.

Mereka mengemasnya dalam puisi, film, tulisan, dan segala hal yang bisa membuat para pendamping dan teman-teman lain bisa mengerti karya apa yang selama ini mereka buat, serta kegiatan belajar seperti apa yang mereka lakukan satu semester. Evaluasi yang tak menuntut persaingan, karena yang terasa adalah saling support, saling memberi masukan, dan turut berbahagia atas kenaikan kualitas karya temannya.

Berkaitan dengan pengelolaan pembelajaran KBQT yang diterapkan adalah selalu dirancang secara bersama-sama dan dilaksanakan secara bersama-sama dan dievaluasi bersama-sama, dengan melakukan musyawarah secara mufakat untuk mencapai tujuan yang telah ditetapkan. Pengelolaan tersebut sesuai dengan pendapat Sudjana, (2000, p.17) mengatakan bahwa "manajemen merupakan serangkaian kegiatan, merencanakan, mengorganisasikan, menggerakkan, mengendalikan dan mengembangkan terhadap segala upaya dalam mengatur dan mendayagunakan SDM, Sarana dan prasarana secara efisien dan efektif untuk mencapai tujuan organisasi yang telah ditetapkan".

Adapun mengenai pelaksanan pendidikan alternatif berbasis komunitas dalam pengelolaan program pendidikan melalui pembelajaran, peneliti membahas yang berkaitan dengan perencanaan pembelajaran, pelaksanaan pembelajaran dan evaluasi pembelajaran

Secara individual anak disuruh mengindentifikasikan kebutuhannya masing-masing yang disesuaikan dengan bakat dan minatnya. Karena dengan begitu maka proses pembelajaran akan menjadi benarbenar dibutuhkan oleh individu dan menjadikan pembelajaran yang menyenangkan. 
Selain itu, identifikasi kebutuhan pembelajaran dilakukan juga setiap masingmasing individu setiap minggunya. Individu melalukan identifikasi berkaitan dengan pembelajaran yang akan dilakukan selama seminggu kedepan.

Perumusan tujuan pembelajaran komunitas yaitu tujuan output atau keluaran dan tujuan outcome atau dampak, atau dapat dikatakan tujuan jangka pendek dan tujuan jangka panjang. Adapun tujuan output atau jangka pendek meliputi karya yang dihasilkan warga belajar, dan outcome atau jangka panjang meliputi pengembangan ketrampilan hidup untuk terus bisa berkarya dalam kehidupan yang akan datang.

Inilah yang membedakan antara pendidikan formal pada umumnya. Kalau di pendidikan formal itu lebih mementingkan akademik atau prestasi, sehingga ada persaingan antara siswa dalam belajar, sehingga ada hal-hal yang tidak diinginkan akan terjadi, seperti menghalalkan segala cara dalam hal ulangan misalnya menyontek buku, menyontek temannya. Iya karena mereka dalam belajar seolah-olah tidak dibutuhkan dalam dunia kehidupannya atau belajarnya tidak bisa menjawab persoalanpersoalan masalah dalam hidupnya. Seperti yang dikatakan oleh Illich (1972) menggambarkan bahwa sekolah memonopoli pendidikan dan lebih menitikberatkan produknya berupa lulusan yang hanya didasarkan atas hasil penilian dengan menggunakan angka dan ijazah. (Sudjana 2001, p.83).

Berbeda dengan konsep pembelajaran di komunitas belajar ini yang mengedepankan karya, jadi setiap warga belajar diwajibkan mempunyai karya dan dengan karya maka warga belajar tidak bisa mencontek persis sama milik karya temannya. Justru dengan karya ini, masing-masing anak akan saling membantu dalam pembuatan karyanya dan tidak ada yang namanya kompetisi dalam membuat karya yang adalah saling memberikan masukan terhadap karya yang telah dihasilkan.

Adapun berkaitan dengan pendekatan pembelajarannya adalah student center atau pendekatan berpusat pada siswa yaitu, siswa aktif dalam melakukan pembelajaran, bukan pasif seperti yang dilakukan pada sekolah formal.

Selanjutnya berkaitan dengan pembelajaran yang dilakukan adalah menggunakan metode active learning merupakan metode pembelajaran yang memposisikan warga belajar sebagai subjek dalam sistem pembelajaran. Dengan begitu warga belajar banyak melakukan diskusi atau sharing pendapat. Saling memberikan pengetahuan dan menambahkan pengetahuan sesama komunitas. Selain itu model pembelajaran yang dilakukan setelah melakukan observasi partisipan, menurut peneliti KBQT Salatiga dalam model pembelajarannya menggunakan Community Based Education (CBE) sebagai model pendidikannya, yaitu model pendidikan yang menyatu dengan masyarakat, pengelola, pendamping, dan warga belajar adalah masyarakat sekitar.

Model pendidikan ini memberikan keutungan bagi warga belajar, karena mereka tidak merasa jauh dengan realistas sehari-harinya, atau tidak tercabut dari akar lokalitasnya sehingga ketika lulus mereka tidak merasa gagap menghadapi permasalahan yang akan datang yang muncul di lingkungannya kelak.

Karena dalam pembelajarannya tidak adanya jarak atau menjauhi masyarakat. Akan tetapi malah sebaliknya, dalam komunitas sangat berbaur sekali dengan masyarakat, karena memang tidak ada sekat dalam lingkungan pembelajarannya seperti di sekolah formal pada umumnya yang dibatasi tembok yang tinggi dan masyarakat tidak mengetahui kegiatan apa yang dilakukan dibalik tembok yang tinggi tersebut.

Teknik dalam pembelajaran yang dilakukan adalah masing-masing anak membuat ide yang selanjutnya diwujudkan dalam target dan capain-capaian yang telah dilakukan dan selanjutnya dievaluasi.

Selama kurang lebih selama hampir satu tahun peneliti melakukan observasi di lapangan, walaupun dilakukan tidak rutin, peneliti merasa sarana dan prasarana yang dimiliki KBQT cukup lengkap dalam mendukung kegiatan pembelajaran yang dilakukannya, walaupun tidak selengkap dan semahal sarana dan prasarana yang ada di sekolah formal, karena memang untuk biaya 
sekolah atau pendidikannya sudah berbeda sangat jauh sekali.

Sarana prasarana itu seperti saja mengenai tempat pembelajaran sudah dibangun gedung yang dinamakan dengan RC (resort center) yang diartikan sebagai lumbung atau tempat tersedianya barangbarang yang dibutuhkan oleh komunitas.

Adapun terkait dengan sarana dan prasarana yang digunakan dalam proses pembelajaran seperti yang dimaksud adalah alat-alat musik, peralatan pembelajaran, LCD proyektor, buku-buku, yang semuanya itu selain ada yang beli juga diberikan oleh pemerintah dan tamu yang berdatangan sebagai kenang-kenangan. Selain itu ada fasilitas internet yang digunakan untuk berselancar mencari pengetahuan-pengetahuan sesuai dengan bakat dan minatnya dan juga sebagai hiburan dalam waktu luangnya.

Selain itu berkiatan dengan tempat pembelajaran, di komunitas belajarnya dilakukan sesuai dengan kesepakatan komunitas. Setelah peneliti melakukan observasi di lapangan, mengenai tempat dan kapan pembelajarannya memang tidak tentu. Kadang pembelajarannya ada yang dimulai pagi hari, ada yang dimulai dari siang hari.

Tempat kegiatan pembelajaran semua, sebenarnya dilakukan sesuai dengan kesepakatan komunitas, baik dari kumpul forum, kumpul kelas yang sesuai dengan yang dikatakan warga belajar sendiri yang mengalami yaitu "pembelajarannya dilakukan kebanyakan di gedung RC dan kadang juga di teras dan di mushola. Intinya tergantung kelas atau forumnya masing-masing".

Berkaitan dengan materi dan bahan pembelajaran yang digunakan adalah berdasarkan kebutuhan komunitas atau individual itu sendiri. Acuan utama dalam pembelajarannya adalah disesuaikan dengan kurikulum yang diyakini sangat berhubungan langsung dengan kehidupannya yang disebut kurikulum KBK, yaitu kurikulum berbasis kebutuhan. Misalnya warga belajar butuh belajar mengenai dunia komputer, maka warga belajar sebelum melakukan berlajar bersama-sama ada yang mencari referensi dulu di internet dan setelah itu sharing pengetahuan antar temannya.
Berkenaan dengan materi belajar dan bahan belajar dapat disimpulkan bahwa materi dan bahan pembelajaran komunitas belajar adalah dari internet dan juga dari sharing pengetahuan dari teman dan lingkungannya. Selain itu membaca buku baik dari buku yang dibelinya sendiri, juga buku yang ada di perpustakaan. Selain itu juga komunitas juga mempunyai komunitaskomunitas di luar, biasanya komunitas di facebook atau mencari komunitas yang dirasa dapat membantu mereka dalam berkarya.

Kegiatan pembelajaran yang dilakukan oleh komunitas adalah kegiatan adalah aktivitas belajar yang dilakukan selama seminggu dari hari senin sampai kembali hari senin lagi. Peneliti menyimpulkan bentuk kegiatannya mempunyai nama-nama yang bisa dikatakan unik, antara lain: upacara, tawasi, harkes, kumpul kelas, kumpul forum, gelar karya.

Upacara adalah kegiatan yang dilakukan oleh komunitas baik dari semua kelas dan semua forum yang diselenggarakan setiap hari Senin untuk melakukan evaluasi mingguan tentang permasalahan yang ada di komunitas, baik permasalahan individu, kelas dan rencana kegiatan yang akan dilakukan, misalnya kegiatan pentas, pembayaran iuran bulanan.

Bentuk kegiatannya kumpul dalam satu ruangan, ada yang menjadi moderator yang biasanya oleh warga belajar yang setara kelas 3 SMA dan yang lainnya memberikan usul dan sarannya masing-masing. Jadi kegiatan upacara ini mirip dengan diskusi untuk mencapai mufakat antar komunitas yang dipimpin oleh seorang moderator. Dalam kegiatan upacara ini juga ada pendamping yang ikut hadir, biasanya yang hadir adalah pendamping inti.

Tawasi adalah kegiatan rutin yang dilakukan sehabis sholat nduhur dan mengaji bersama setiap hari senin s/d kamis. Adapun kegiatannya adalah melafadzkan asmaul husna (nama-nama Allah) dan dilanjutkan membawa ayat suci alqur'an setelah itu ada salah satu warga belajar yang mempresentasikan materi yang sifatnya mengingatkan teman-temannya. Adapun dari presentasi tersebut, apabila ada teman 
atau pendamping yang mempunyai pengetahuan dan pengalaman, bisa saling melengkapi pengetahuan dan saling bertanya jawab, sehingga akan menciptakan interaktif dalam proses pembelajaran. Kegiatan tawasi ini biasanya dipimpin oleh Pak Ridwan sebagai pak Kyai atau Ustadz karena sehariharinya dia selalu memakai songkok yang selalu membantu dalam komunitas. Biasanya yang mengikuti selain warga belajar juga ada pendirinya Pak Din, jika beliau tidak keluar kota atau ada kegiatan.

Harkes adalah kegiatan pembelajaran yang dilakukan setiap hari sabtu. Adapun bentuk kegiatannya adalah materi tanya jawab mengenai dunia seputar kesehatan dan juga olahraga yang biasanya didampingi oleh pendamping. Biasanya kegiatannya yang dilakukan dalam sebulan adalah dua kali teori atau diskusi dan dua kali olahraga. Kegunaan harkes adalah untuk menambah pengetahuan seputar kesehatan yang berguna untuk pencegahan/preventif. Alasan diadakan Harkes ini dikarenakan apapun pekerjaannya ternyata kesehatan itu sangat penting dan harta yang paling berharga. Sehingga dengan adanya harkes dimungkinkan komunitas tidak akan terkena penyakit atau jika menderita penyakit, maka akan bisa cepat lekas sembuh.

Kumpul kelas atau pertemuan yang diadakan masing-masing dalam kelas yang jadwalnya sesuai dengan kesepakatan bersama-sama. Adapun nama-nama kelasnya dari awal komunitas ada sampai sekarang nama kelasnya berbeda-beda. Mengenai pemberian nama kelas disepakati bersama oleh kelas itu sendiri, jadi tidak sama tiap tahun atau ajaran barunya. Adapun untuk nama kelasnya antara lain sebagai berikut: (a) THE NAIN artinya sembilan, karena muridnya berjumlah 9 warga belajar yang setara 1 SMP, (b) SEDDU (seed education) yang artinya benih pendidikan, yang setara 3 SMP, (c) OSA (oriza satifa) seperti pada, semakin berisi semakin merunduk) yang setara 1 SMA, (d) EKQ (elecktro kardiografi) alat detak jantung, karena kelas ini dulunya hampir mati, yang setara 2 SMA, (e) SARUNGI (sayuk rukun ngudi ilmu) bersama-sama rukun dalam mencari ilmu yang setara 3 SMA
Kumpul forum adalah kegiatan yang dilakukan oleh warga belajar yang memunyai ketertarikan atau kesenangan dalam belajarnya. Warga belajar dalam memilih forum tidak diharusnya hanya memilih satu saja, akan tetapi jika minat mengikuti dua forum atau tiga juga tidak apa. Adapun berkaitan dengan forum dapat di kelompokkan sebagai berikut: (a)Musik, (b) Teather, (c) Tulis, (d) Lukis, (e) Komputer, (f) Bahasa, (g) Sanggar.

Gelar karya adalah kegiatan yang dilakukan setiap enam bulan sekali untuk menampilkan karya yang telah dihasilkan selama enam semester atau ritual yang dilakukan sebelum naik kelas. Kegiatan ini yaitu setiap individu mempresentasikan hasil karyanya di depan teman-temannya dan pembimbing, selanjutnya teman-teman memberikan kritik dan sarannya sesuai dengan pengetahuannya demi menjadikan karya akan lebih sempurna dan lebih bermanfaat untuk dirinya dan juga mungkin orang lain.

Setelah dilakukan gelar karya individu juga biasanya dilakukan gelar karya per kelas dan per forum. Adapun kegiatan gelar karya biasanya disela-sela presentasi dari masing-masing individu ada semacam hiburan dari individu atau dari forum. Tak ketinggalan biasanya pendamping Tawasi Pak Ridwan dengan Suloknya mengumandangkan sholawatan dan Pak Awik sebagai pendamping musik mengirinya.

Kegiatan gelar karya ini biasanya dilakukan dari pagi sampai sore hari dan semua pendamping, warga belajar dan pendiri juga hadir untuk menikmati karya-karya komunitas dan memberikan semangat dan kritik dan saran yang membangun untuk karya-karya komunitas ke depannya.

Berkaitan dengan evaluasi pembelajaran atau penilaian dalam pembelajaran dalam KBQT dilakukan oleh dirinya sendiri. dengan kata lain sistem evaluasi berpusat pada peserta didik. Puncak keberhasilan pembelajaran adalah ketika si subjek didik menemukan dirinya, berkemampuan mengevaluasi diri sehingga tahu persis potensi yang dimilikinya, dan berikut mengembangkannya sehingga bermanfaat bagi yang lain. 
Berkenaan dalam hal penilaian pembelajaran warga belajar yang disuruh menentukan sendiri penilainnya. Penilaian pembelajaran bukan dilakukan oleh guru/ pendamping dan baik atau buruk nilainya bukan ditentukan karena bisa menjawab atau tidak menjawab soal pertanyaan yang diberikan, akan tetapi warga belajar mampu tidaknya melaksanakan rencana target bulanan atau semesteran yang telah ditetapkan sebelumnya. Jika targetnya bisa dilakukan atau sesuai dengan rencana yang rancang, maka dinilai berhasil dan sebaliknya.

\section{Hasil Pembelajaran}

Hasil pembelajaran yang berbentuk karya yang tak menuntut persaingan, karena bukan prestasi yang diunggulkan, melainkan sebuah karya sesuai dengan bakat dan kesukaan masing-masing individu dengan suasana yang terasa adalah saling support, saling memberi kritik dan saran serta masukan, atas kenaikan kualitas karya yang dipresentasikan di depan teman-temannya, pendampingnya dan juga pendirinya.

Berkaitan dengan output/keluaran warga belajar nantinya akan bisa mandiri dan dengan mudah menyesuaikan dengan lingkungan masyarakatnya, dikarenakan pembelajaranya tidak tidak tertutup dengan masyarakat. Berkaitan dengan karya yang dihasilkan antara lain sebagai berikut: seni musik, seni tari, seni rupa, karya tulis, keterampilan lainnya.

Seni musik: mempunyai group band dan juga group jimbe yang masih eksis dan apabila ada acara sering diundang untuk memeriahkan acara. Seni tari: mempunyai group dancer, wushu yang selalu ikut dalam lomba tingkat daerah Seni rupa: komunitas berkarya dalam menggambar, membuat komik. Karya tulis: komunitas dengan karyanya membuat cerpen puisi, novel dan juga buku-buku yang sudah banyak di terbitkan oleh percetakannya sendiri dan juga percetakan ternama seperti LKIS. Ketrampilan lainnya: komunitas dapat melakukan ceramah atau dialog dengan menggunakan bahasa Inggris, Arab, membuat manikmanik, stiker dan desain busana yang unik.
Sementara yang berkaitan dengan outcome/hasil pembelajaran warga belajar akan mempunyai ketrampilan yang lebih, sehingga dapat diterima dan tidak dipandang sebelah mata oleh masyarakat, karena dalam pembelajarannya selalu mengedepankan diskusi secara musyawarah dalam mencapai mufakat.

\section{Faktor Pendukung dan Penghambat}

Faktor pendukung komunitas ternyata adalah teman itu sendiri, selanjutnya pendamping yang mendampingi dalam proses pembelajaran. Teman adalah merupakan faktor pendukung utama, karena dalam pembelajaran komunitas adalah lingkungan utama dalam mempengaruhi pembelajaran. Jika antarteman saling memberikan dorongan yang menjadikan semangat, maka dalam belajar akan semangat, begitu juga sebaliknya.

Faktor penghambat dalam komunitas disebabkan oleh dua faktor internal dari dalam diri sendiri dan faktor eksternal dari luar.

Faktor dari dalam diri pembelajar itu sendiri, dimana mereka belum mengetahui atau memahami konsep pembelajaran komunitas. Sehingga apabila para warga belajar kurang memahami konsep pembelajaran, maka mereka tidak akan bisa maksimal dalam proses pembelajaran mengembangkan potensi yang ada dalam diri mereka.

Faktor dari luar diri pembelajar itu sendiri, yaitu pendamping belajar yang kurang memberikan perhatian yang lebih untuk menyemangatinya. Karena secara psikis jiwa anak masih labil, untuk itu sebagai pendamping harus selalu memberikan support atau dukungan secara rutin dalam memberikan semangat belajar kepada warga belajar.

\section{SIMPULAN DAN SARAN}

\section{Simpulan}

Berdasarkan filosofi pendidikannya yang digunakan adalah menggunakan filsafat kontruktivisme mengenai pemikiran belajarnya dengan dihadapkan pada permasalah yang berhubungan langsung dengan 
kehidupan masyarakat sehingga setelah kembali ke daerah asal atau lingkungannya tidak kaku atau beradaptasi lagi. Selain itu dalam filofosi pembelajarannya menggunakan filosofi rekontruktivisme yaitu dalam pembelajarannya melakukan perbaikan-perbaikan dalam kesalahan yang telah dilakukan sebelumnya dengan malakukan evaluasi kehidupannya sesuai dengan target atau capainnya.

Pengelolaan program pendidikan melalui pembelajaran dibagi menjadi tiga bagian yaitu (a) Perencanaan pembelajaran: yang dirancang oleh untuk bagi komunitas yang disesuaikan berdasarkan kurikulum berbasis kebutuhan, (b) Pelaksanaan pembelajaran dilakukan seminggu antara lain: upacara, tawasi, harkes, kumpul kelas, kumpul forum, gelar karya, (c) Evaluasi pembelajaran: dilakukan sendiri dengan pengawasan temannya sendiri yang berpatokan pada ide, target, capaian selama seminggu yang telah dilakukan oleh masing-masing individu.

Mengenai hasil pembelajarannya dapat dilihat yaitu setelah melakukan pembelajaran selama satu semester atau setengah tahun yang disesuaikan dengan target masing-masing warga belajar. Adapun hasil belajarnya berupa produk karya berkaitan dengan hobby atau bakat dan minat warga belajar tersebut yang ditampilkan dalam GK (gelar karya).

Faktor pendukung dan penghambat dalam pembelajaran dibagi menjadi dua diantara, faktor internal yaitu memahami konsep pembelajaran komunitas dan faktor eksternal yaitu pendamping belajar yang kurang memberikan perhatian yang lebih dalam mendampinginya belajar.

\section{Saran}

Kepada penyelenggara: perlu adanya pendampingan yang lebih fokus lagi kepada masing-masing individual, supaya pembelajarannya benar-benar maksimal dan warga belajar secara optimal dapat mengembangkan potensi dan bakat yang dimilikinya.

Kepada komunitas: perlu adanya konsep penyadaran kepada warga belajar, sebelum awal pembelajaran dilakukan, agar masing-masing individu dalam pembelajar- an bisa berjalan dan terlaksana dengan lancar sesuai dengan 7 prinsip-prinsip dalam pembelajaran komunitas.

Kepada pemerintah: agar memperhatikan pendidikan nonformal, khususnya komunitas belajar qaryah thayyibah yang keberadaannya tidak dipandang oleh sebelah mata. Untuk itu perlu adanya pendampingan-pendampingan yang dilakukan agar pendidikan alternatif seperti ini bisa dilaksanakan di setiap daerah.

\section{DAFTAR PUSTAKA}

Dwiningrum, Siti Irine Astuti. (2011). Desentralisasi dan partisipasi masyarakat dalam pendidikan. Yogyakarta: Pustaka Pelajar

Friere, P. (2000). Pendidikan kaum tertindas. (Terjemahan Otomo Dananjaya, dkk). Jakarta: LP3ES. (Buku asli diterbitkan tahun 1972).

Hasbullah. (1999). Dasar-dasar ilmu pendidikan. Jakarta: PT Raja Grafindo Persada.

Isjoni. (2012). Memajukan bangsa dengan pendidikan. Yogyakarta: Pustaka Pelajar.

Kamil, Mustofa. (2009). Pendidikan nonformal. Bandung: Alfabeta.

Kompas. (2007). Kurikulum yang mencerdaskan visi 2030 dan pendidikan alternatif. Jakarta: PT Kompas Media Nusantara

Mohammad, Ali. (2009). Pendidikan untuk pembangunan nasional. Bandung: PT Imperial Bhakti Utama

Prasojo, Lantip D. (2012). Finansial recources sebagai faktor penentu dalam implementasi kebijakan pendidikan. Jurnal Internasinal.

Rifai, Mohamad. (2011). Politik pendidikan nasional. Yogyakarta: Ar-ruzz Media

Rogers, A. (2005). Non-formal education: flexible schoolong or participatory education. New York: Kluwer Academic Publishers 
62- Jurnal Pendidikan dan Pemberdayaan Masyarakat, Volume 1 - Nomor 1, Maret 2014

Shaleh, Ahmad Nazili. (2011). Pendidikan dan masyarakat. (Terjamahan Syamsuddin Asyrofi). Yogyakarta: Sabda Media. (Judul Buku Asli Al Tarbiyyah wal Mujtama').

Sudjana, Djuju.(2000). Manajemen program pendidikan: untuk pendidikan luar sekolah dan pengembangan sumberdaya manusia. Bandung: Falah Production
.(2001). Pendidikan luar sekolah, wawasan, sejarah perkembangan, falsafah, teori pendukung, asas. Bandung: Falah Production

Suharto, Edi. (2010). Membangun masyarakat memberdayakan rakyat. Bandung: PT Rafika Aditama.

Zamroni. (2000). Paradigma pendidikan masa depan. Yogyakarta: Bigraf Publising 